\title{
THE EFFECTS OF HORMONAL THERAPY AND EXERCISE ON BONE TURNOVER IN POSTMENOPAUSAL WOMEN: A RANDOMISED DOUBLE-BLIND PILOT STUDY
}

\author{
Suzy Y Honisett ${ }^{1}$, Kathy Tangalakis ${ }^{1}$, John Wark ${ }^{2}$, Vasso Apostolopoulos ${ }^{1}$, \\ Lily Stojanovska ${ }^{1, *}$ \\ ${ }^{1}$ Centre for Chronic Disease, College of Health and Biomedicine, Victoria University, \\ Melbourne VIC Australia \\ ${ }^{2}$ Royal Melbourne Hospital, Parkville, Melbourne VIC Australia
}

Corresponding Author: Centre for Chronic Disease, College of Health and Biomedicine, St Albans Campus, Victoria University, VIC 3021, Australia; tel: +613 99192737; fax: tel: +613 99194565; e-mail: lily.stojanovska@vu.edu.au (L. Stojanovska)

\begin{abstract}
Introduction: Hormone replacement therapy (HRT) and walking were investigated independently and in combination, to determine which treatment provided most effect on bone turnover in postmenopausal women.

Methods: Using a randomised double-blind pilot study, 10 subjects received HRT (transdermal estradiol, $50 \mu \mathrm{g} /$ day and oral MPA $5 \mathrm{mg} /$ day) and 12 received placebo for 20 weeks. Following a baseline period of treatment, both groups undertook a graduated walking regimen, which increased in intensity, duration and frequency parameters from weeks 8-20. Measurements of aerobic capacity, female sex hormones, bone formation markers [osteocalcin (OC) and bone alkaline phosphatase (BAP)] and bone resorption markers [deoxypyridinoline (DPD) and pyridinoline (PYR)] were measured at baseline (T1), week 8 (T2) and week 20 (T3).

Results: Age, time of postmenopause, weight or body mass index were no different between each groups. The HRT group had significantly higher estradiol levels compared with the placebo group at T2 and T3. FSH and LH levels were significantly reduced following HRT. DPD and PYR were significantly reduced from baseline levels at T2 and T3 with HRT. No significant changes occurred in OC or BAP levels with either HRT or walking. Walking did not change bone turnover markers in either the HRT or placebo group.

Conclusion: HRT reduces bone resorption, however, walking alone at the intensity and duration prescribed, or the combination of HRT and walking, provided no additional benefit after menopause. Therefore, HRT, but not walking is an effective treatment in reducing bone turnover in postmenopause women.
\end{abstract}

Keywords: Exercise, Hormone replacement therapy, HRT, Bone turnover, Menopause, Estrogen

\section{Introduction}

Menopause is associated with endocrine changes, including significant reductions in estrogen and progesterone levels, and alterations in the pituitary gonadotrophins, follicle stimulating hormone (FSH) and leutinising hormone (LH). Other age associated changes that occur with ageing, that are superimposed on estrogen deficiency include elevated serum parathyroid hormone (PTH) and attenuated calcitriol levels.
These changes have been implicated in altered bone metabolism and reduced skeletal integrity after menopause.

Bone metabolism can be assessed by the measurement of biochemical markers that are released into the circulation and urine, providing chemical indices for whole body bone turnover [1-9]. The level of these biochemical markers can predict bone density and rates of bone loss in postmenopausal populations [10]. 
The relationship of bone turnover markers to changes in bone mineral density (BMD) is inverse in states of altered bone remodeling [11], providing a cost effective, potentially useful tool for the prediction of the bone responses to changes in bone remodeling [11].

Menopause is associated with a 79-97\% increase in bone resorption markers, whilst bone formation markers are increased by $37-52 \%$, reflecting an overall increase in bone turnover [12]. Alterations in bone turnover markers precede changes in bone mass and density. BMD is reduced in the initial 3 to 12 months after the last menses by $0.9 \%$ at the lumbar spine and $0.7 \%$ in the femoral neck [13]. This attenuation of bone is associated with reduced circulating estrogen levels. The bone loss experienced in the initial 6 years after menopause is estimated to be approximately $15 \%$ [14], imposing a considerable risk for the development of osteoporosis.

Increasing age is typically associated with reduced levels of physical activity. A reduction in weight bearing exercise, and less frequent involvement in exercise that provides mechanical loading on bones, are potentially associated with lowered bone density and an increased risk of fracture. This is shown in immobility [15] and space flight [16] studies where there is little or no mechanical strain or loading on bone and a subsequent deterioration in bone density occurs.

Hormonal replacement therapy (HRT) containing estrogen, and physical activity are commonly prescribed as independent interventions for reducing the risk of osteopenia after menopause. Estrogen plays a major role in bone metabolism and cytokines production, which maintains the quality of bone and alveolar bone crest [17]. The signal transduction pathways for estrogen and the mechanical strain appear to share common elements [18], and both interventions may be relevant in the prevention of postmenopausal osteoporosis.

The most effective type and intensity of exercise, to provide the greatest benefit to bone whilst fostering compliance, remain to be fully elucidated. Whilst bone mineral density (BMD) and HRT have been extensively researched, there has been little investigation into bone turnover changes as a result of exercise either independently, or combining these 2 interventions in a postmenopausal population. We pro- posed that moderate exercise in the form of brisk walking would induce a weight-bearing mechanical load on bone, whilst providing an accessible and safe form of exercise for women who do not participate in any regular or structured form of exercise. Herein, we evaluated the effect of low intensity exercise in the form of walking and HRT independently, and when combined, on bone turnover markers in postmenopausal sedentary women.

\section{Methods}

\section{Postmenopausal subjects}

Twenty eight postmenopausal women were recruited from the general public via advertisements in local papers. Six women withdrew from the study; one woman moved away during the course of the study; two women suffered skin irritation caused from the transdermal estrogen; two women withdrew due to lack of time available to continue involvement; one woman was excluded prior to commencement due to excessive alcohol intake. Twenty two women completed the study. The criteria for inclusion were 1-5 years postmenopause; aged between 45-60 years. The criteria for exclusion were; taking any form of hormonal replacement therapy; previous hysterectomy or oophorectomy; family history of estrogen dependent malignancies; established cardiovascular disease; involved in any regular form of structured exercise; smoking; taking any drug therapy or having any disease that would affect the gain/loss of bone mineral. All women were cleared for participation following a full physical examination by a clinician.

Women were randomly assigned into 2 groups. Ten women were assigned into the 'HRT group', and commenced using transdermal estradiol patches (Estraderm $50 \mu \mathrm{g}$, Novartis Pharmaceuticals, North Ryde, NSW, Australia) changed twice weekly, and oral medroxyprogesterone acetate (MPA, 5mg/day) (Pharmacia Pharmaceuticals, Rydalmere, NSW, Australia). Twelve women were assigned to the 'placebo' group and commenced using placebo transdermal patches and oral placebo tablets. All subjects participating in this study were asked to maintain their current dietary habits throughout their involvement in the study. All women gave infor- 
med consent to participate in this study, which was approved by the Human Ethics Committee, Victoria University (991017/CO484).

\section{Protocol}

Subjects were tested three times over the duration of the twenty week study. Measurements were taken at baseline ( $\mathrm{Tl})$, prior to commencement of exercise training, at eight weeks (T2) and on completion of the study, at twenty weeks (T3). Height and weight were determined for all subjects. At each time point, aerobic capacity was determined by measures of $\mathrm{VO}_{2}$ peak. In addition, morning fasting blood samples were taken for measurement of estradiol, leutinising hormone (LH) and follicle stimulating hormone (FSH) and bone formation markers, bone alkaline phosphatase (BAP) and osteocalcin (OC). Urine samples were taken 2 hours post first morning void, at the above intervals for measurement of the bone resorption markers, pyridinoline (PYR) and deoxypyridoline (DPD).

Subjects continued their specified treatment regimen throughout the 20 week period. After 8 weeks, subjects initiated an exercise training program whilst continuing their specified treatment regimen. This program was individually based on each participant's baseline fitness level. From baseline aerobic capacity measures, volume of expired carbon dioxide $(\mathrm{ml} / \mathrm{kg} / \mathrm{min})$ was plotted against the volume of expired oxygen $(\mathrm{ml} / \mathrm{kg} / \mathrm{min})$. A parallel graph, plotting ventilation $(\mathrm{L} / \mathrm{min})$ against oxygen consumption $(\mathrm{ml} / \mathrm{kg} / \mathrm{min})$ was determined for the duration of the test. A non-linear fit was assessed for each graph and the maximum of the second derivative was determined as the inflection point, noted as the anaerobic threshold. The heart rate at anaerobic threshold was used to calculate the training heart rate. Individuals underwent a 12 week walking program. Exercise intensities assessed by heart rate monitoring commenced at $70 \%$ of the baseline anaerobic threshold and increased by $5 \%$ every second week to $95 \%$ of anaerobic threshold over the following 12 week period. The participants achieved the increments in heart rate by increasing the speed of walking, or walking on an incline. The duration of exercise at the specified heart rate commenced at 10 minutes and increased by 5 minutes duration every second week to a total of 35 minutes at twenty weeks. A
5 minute warm up and cool down preceded and followed each walking session. Lastly, the frequency of exercise sessions performed per week commenced at three, and increased by one session per week on a monthly basis. Two women suffered skin irritation caused from the transdermal estrogen, whilst there were no adverse effects of involvement in the walking program.

\section{Assays}

Estradiol was measured using a competitive chemiluminescent immunoassay (Ciba Coming, Medfield, MA, USA). FSH and LH were measured using a two-site chemiluminescent (sandwich) immunoassay (Ciba-Coming, Medfield, MA, USA). BAP was measured using the standard autoanalyser ELISA technique (Alkaphase B96, Metra Biosystems). Serum OC was measured by radioimmunoassay using the osteocalcin RIA kit (Incstar Corp., Stillwater, MN, USA). Free PYR and DPD cross links were measured on morning void urine samples by an enzyme linked immunosorbent assay (ELISA) using rabbit antipyridinoline (Pyrilinks, Metra Biosystems, Palo Alto, CA, USA) and expressed as pyridinoline/creatinine ratio (PYR nmol/mmol $\mathrm{Cr}$ ).

\section{Aerobic Capacity}

Aerobic fitness was determined via a $\mathrm{VO}_{2}$ peak test. This test measures oxygen consumption per minute during exercise to peak levels. Measurement to maximum levels was deemed less safe within this population. Hence, a $\mathrm{VO}_{2}$ peak test was used instead of a $\mathrm{VO}_{2}$ max protocol. The laboratory where the trials were conducted was maintained at a constant temperature $\left(20 \pm 1{ }^{\circ} \mathrm{C}\right)$ and humidity $(44 \pm 2 \%)$. A 12 lead electorcardiogram (ECG; Montara, X-scribe, Stress testing System, Milwaukee, U.S.A.) was used to monitor subjects' heart rhythm and rate throughout the duration of the test. Subjects exercised on a stationary bicycle ergometer (Cybex Metabolic Systam, Met 100, Huntsville, USA) at a constant cadence of 70 rpm. Increments in intensity occurred each minute, starting at 35 watts and increasing by 10 watts each minute. These increments continued until the subject was exhausted, or until the subject experienced discomfort, or the practitioner observed significant ECG changes. Each subjects' oral gas expiration was measured via Vacumetric Vista Turbofit Software package (Version 3.2, Ametek, Pittsbergh, USA) to de- 
termine their respiratory exchange ratio and aerobic capacity. Subjects were deemed to have reached their $\mathrm{VO}_{2}$ peak when at least two of the following criteria were achieved (a) a plateau of $\mathrm{VO}_{2}$ peak readings over 3 consecutive recordings, (b) exercising heart rate to within 10 beats of subjects' maximal heart rate, calculated as 220 minus age, (c) a respiratory exchange ratio (RER) of greater than 1.10.

\section{Statistical Analysis}

Data were analysed using SPSS (10.0). Data reported are mean \pm standard error of the mean. Repeated measures analysis of variance was used to determine significance. Post-hoc analysis of group differences was carried out using a Student's unpaired t-test. Significance was reported at $p<0.05$.

\section{Results}

There was no significant difference in age $(51.1 \pm 2.1$ vs. $51.6 \pm 1.7$ years $)$ and time postmenopause $(2.3 \pm 1.1$ vs. $1.6 \pm 0.2$ years $)$ between groups taking hormonal replacement therapy and those taking placebo. Similarly, there were no significant differences in weight or body mass index (BMI) between or within groups for the duration of the study (Table 1). Estradiol was significantly higher in the HRT group in comparison to the placebo group at $\mathrm{T} 2$ and T3. FSH and LH were significantly decreased at T2 and T3 compared with baseline levels in the same group (Table 1). The increased estradiol and simultaneous significant reduction in plasma FSH and LH ascertain that subjects were compliant with HRT, which was supported by medication counts. Bone resorption markers (DPD and PYR) were both significantly reduced from baseline levels with HRT administration (T2) (Table 1, Figures 1 and 2) and were significantly lower than the placebo group at T2. Bone resorption markers were unchanged as a result of exercise. Although slightly reduced, neither BAP nor OC showed significant reductions as a result of HRT or exercise. BAP was significantly lower than the placebo group at T3. There were no significant changes to $\mathrm{VO}_{2}$ peak as a result of exercise training in rate, respiratory exchange ratio and exercise duration were unchanged in both groups as a result of the exercise training regimen over a 12 week period.

Table 1

Personal, Hormonal, Fitness and Bone parameters

\begin{tabular}{|l|l|l|l|l|l|l|}
\hline & Baseline & Placebo & $\begin{array}{l}\text { Placebo \& } \\
\text { exercise }\end{array}$ & Baseline & HRT & $\begin{array}{l}\text { HRT \& } \\
\text { exercise }\end{array}$ \\
\hline & T1 & T2 & T3 & T1 & T2 & T3 \\
\hline Weight, kg & $69.4 \pm 4.7$ & $69.7 \pm 4.9$ & $69.3 \pm 4.8$ & $71.8 \pm 7.8$ & $72.1 \pm 7.6$ & $72.5 \pm 7.5$ \\
\hline BMI, kg/m 2 & $26.8 \pm 2.2$ & $26.9 \pm 2.3$ & $26.7 \pm 2.2$ & $27.5 \pm 3.3$ & $27.6 \pm 3.2$ & $27.8 \pm 3.2$ \\
\hline Estradiol, pmol/1 & $77.6 \pm 12.0$ & $89.2 \pm 17.1$ & $73.4 \pm 18.3$ & $100.0 \pm 21.5$ & $166.3 \pm 36.8^{+}$ & $164.9 \pm 29.9^{+}$ \\
\hline FSH, m/u/ml & $57.9 \pm 9.7$ & $51.1 \pm 9.4$ & $56.1 \pm 13.5$ & $77.1 \pm 14.8$ & $39.8 \pm 15.8^{*}$ & $37.1 \pm 14.6^{*}$ \\
\hline LH, m/u/ml & $45.8 \pm 11.8$ & $33.7 \pm 7.3$ & $36.2 \pm 7.2$ & $44.7 \pm 8.9$ & $18.4 \pm 6.8^{*}$ & $19.6 \pm 8.1^{*}$ \\
\hline AC, ml/kg/min & $20.6 \pm 1.9$ & $21.2 \pm 1.7$ & $21.6 \pm 1.7$ & $21.4 \pm 2.6$ & $22.3 \pm 2.7$ & $22.9 \pm 1.9$ \\
\hline $\begin{array}{l}\text { BONE } \\
\text { FORMATION }\end{array}$ & & & & & & 14.9 \\
\hline OC, ug.1 & $17.3 \pm 2.6$ & $17.9 \pm 2.7$ & $17.8 \pm 2.4$ & $15.7 \pm 3.0$ & $15.2 \pm 2.9$ & $14.3 \pm 2.8$ \\
\hline BAP, U/L & $13.6 \pm 2.8$ & $16.8 \pm 2.9$ & $16.8 \pm 3.1$ & $11.1 \pm 3.8$ & $10.6 \pm 4.0$ & $9.5 \pm 4.1^{+}$ \\
\hline $\begin{array}{l}\text { BONE } \\
\text { RESORPTION }\end{array}$ & & & & & & \\
\hline $\begin{array}{l}\text { PYR, } \\
\text { nmomol/mmol Cr }\end{array}$ & $81.0 \pm 16.9$ & $79.6 \pm 15.9$ & $78.1 \pm 13.6$ & $75.5 \pm 15.6$ & $58.6 \pm 12.0 *^{*}$ & $64.9 \pm 14.0$ \\
\hline $\begin{array}{l}\text { DPD, } \\
\text { nmmol/mmol Cr }\end{array}$ & $15.6 \pm 3.1$ & $16.0 \pm 3.3$ & $14.1 \pm 3.0$ & $13.7 \pm 3.2$ & $9.9 \pm 2.4^{*+}$ & $9.5 \pm 2.7$ \\
\hline
\end{tabular}

Abbreviations: BMI, body mass index; FSH, follicle stimulating hormone; LH, luteinising hormone; AC, aerobic capacity: OC, osteocalcin; BAP, bone alkaline phosphatase; PYR, pyridinoline; DPD, deoxypyridionline.

$*(p<0.05)$ Significantly different from T1 H group.

${ }^{+}(p<0.05)$ Significantly different from placebo group at the same time point. 


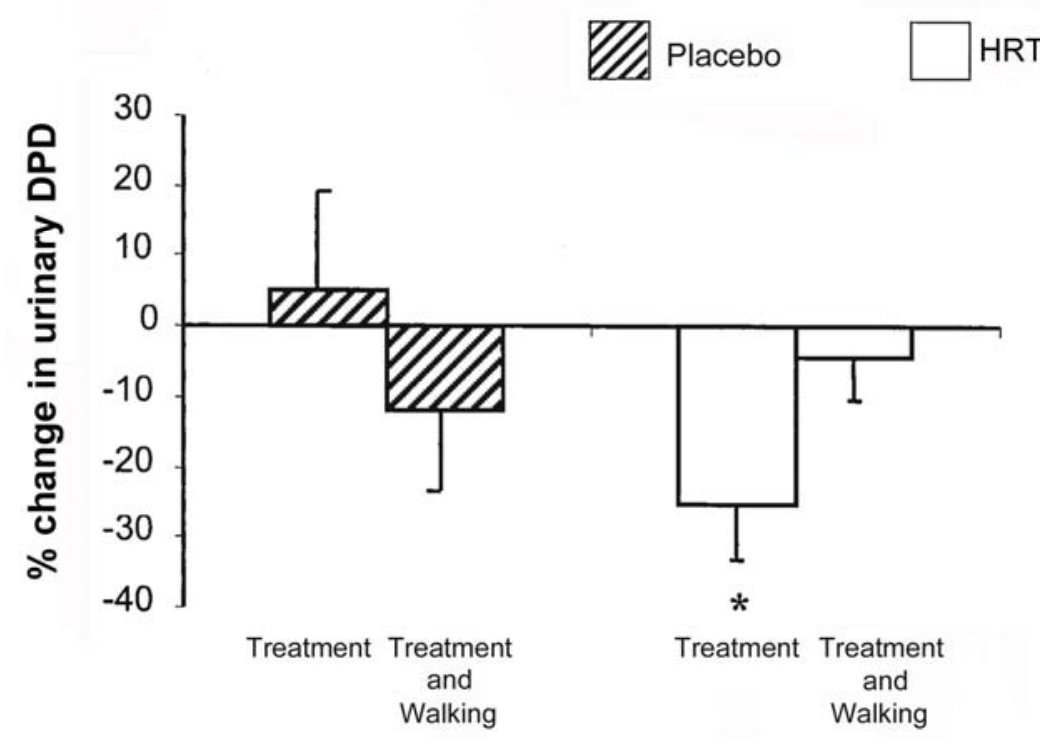

Figure 1 - Urinary Pyridinoline (PYR) excretion percent change in placebo $(n=12)$ and HRT $(n=10)$ groups from baseline levels with hormone or placebo treatment alone and with hormone or placebo treatment and exercise.

( $*$ significantly different from baseline levels, $p<0.05$ )



Figure 2 - Urinary Deoxypyridinoline (DPD) excretion percentage change in placebo $(n=12)$ and $H R T(n=10)$ groups from baseline levels with treatment alone and with treatment and exercise (*significantly different from baseline levels, $p<0.05$ )

\section{Discussion}

The main new findings of this study were that bone resorption indices were significantly reduced after 8 weeks of HRT, whilst bone formation markers remained unchanged. Our results are similar to a previous study [19] that found one year of treatment with estrogen significantly suppressed bone resorption, whilst bone formation remained unchanged, preventing overall bone loss in ovariectomised women, measured by dual energy x-ray absorptiometry (DXA). Furthermore recent studies con- 
ducted in mice shows decreased trabecular thickness, bone density and bone volume and increased trabecular separation caused by overiectomy were prevented by giving estrogen replacement [17].

Sex hormones play a regulatory role in bone metabolism [20]. Estrogen levels correlated with osteoclastic (bone resorption) activity thus increased estrogen levels directly increase osteoclast apoptosis [21]. Reduced estrogen levels that accompany menopause increase cytokine levels- interleukin-1 and tumor necrosis factor alpha, secreted from peripheral blood monocytes [22]. These factors act on stromal osteoblastic precursor cells, and induce secretion of other cytokines interleukin- 6 and interleukin-11, which promote the development of bone resorbing osteoclasts [20, 22, 23]. Thus, estrogen deprivation provides an indirect stimulus as a potent promoter of bone resorption. Combinations of cytokines - interleukin-1, tumor necrosis factor alpha, interferon gammaincreases osteoblastic nitric oxide (NO) production [24], which suppresses bone resorptive osteoclast development and activity, and subsequently reduces resorption. The production of NO by osteoblasts directly regulates osteoclast activity and is perceived to play a regulatory role in conditions of bone such as osteoporosis [1 91. Estrogen replacement down regulates interleukin-6 production $[25,26]$ providing at least one molecular mechanism for the inhibitory effect of hormonal therapy on postmenopausal bone loss.

\section{Exercise effect}

Weight-bearing exercise provides a stimulus of mechanical loading on bone cells, which induces bone formation [27]. The effect of physical activity on human bone has been well documented in a variety of population groups [28-32]. Younger athletes have a greater bone mass in comparison to sedentary controls [30]. Dominant arms of male and female tennis players exhibit up to $28.4 \%$ greater bone thickness and bone mineral content in comparison to non-dominant arms $[31,32]$. The bone response to exercise after menopause, however, has provided varying degrees of both positive results $[33,34]$, results indicating that varying types and intensities of exercise provide no training effect on bone [35-37]. In this study, moderate weight-bearing exercise alone in the form of walking did not alter any bone formation or resorption indices. The intensity, frequency and duration of exercise are important parameters when considering an exercise training regimen. Wolff's law proposes that bone remodeling is directly dependent upon the mechanical load placed on the bone [38]. Alternatively, a strain threshold may exist for the stimulation of osteogenesis. An insufficient application of strain or load may be inadequate to reach the strain threshold, indicating that the magnitude of the strain may be more important than strain frequency. Brisk walking alone may provide an insufficient mechanical strain to overcome estrogen deficiency after menopause. This may explain why, in this study, there was no change in bone turnover markers as a result of walking based exercise training regimen with either HRT or placebo treatment.

\section{Type and intensity of exercise}

There are numerous studies that assess bone mineral changes as a result of exercise in postmenopausal populations. The results of these studies, however, provide conflicting outcomes. Aerobic exercise, involving brisk walking and lifetime volleyball involvement, were unable to counteract an age and, or, menopause related decline in BMD $[35,39]$. BMD primarily at the femoral neck, however, was increased with exercise that involved vigorous walking, jogging, stair climbing, and high impact aerobics [33, $40,41]$ whilst, total body BMD was also augmented $[40,42]$ in a number of these studies. On the other hand, long term vertical jumping exercises using a weighted vest prevented hip bone loss over five years [43]. High intensity aquatic exercise program performed for 24 weeks prevented from reducing BMD by increase bone formation and reduce bone resorption [44, 45]. Resistance and strength training performed for at least one year increased regional BMD at sites of intratrochanter and hip [46], and total body $[42,46]$. Similar programs that were performed for one year or less showed no change in total bone mineral content (BMC) [36], BMD at lumbar spine $[35,37,47]$ or total hip BMD [37]. It should be noted that it is difficult to compare studies due to the differences in exer- 
cise regimen type, intensity and frequency, and subject characteristics such as age, baseline BMD and years since menopause. With increasing age and years postmenopause, there is an accretion in the amount of bone lost; therefore, if women are commencing exercise at lower bone densities there may be a greater effect of treatment.

The age range of the current study was very tight, with all women 49 to 54 years of age, and early postmenopause (1.6 to 2.3 years) and could partly explain the lack of exercise effect in the current study, as women were commencing exercise prior to having lost substantial BMD due to estrogen deficiency. In contrast, previous exercise studies had large ranges for age and the number of years postmenopause, with many studies involving women up to and over 10 years older than women in the current study. The exercise program designed for these women was mild and graduated to minimize the risk that previously sedentary women would not encounter injury throughout the training program. All women remained injury-free for the duration of their involvement. Walking was chosen as the mode of exercise due to the weight-bearing nature and ease of administration. It was also perceived that previously sedentary women would be more compliant with this mode of exercise, which was verified by subjects' diarising involvement in walking sessions. The moderate nature of the exercise program did not increase the $\mathrm{VO}_{2}$ peak of the subjects, nor alter weight or BMI.

Vibration exercise is one of the safest activities for osteoporosis women that prevent falls. Whole-body vibration strategy is used in preventing sarcopenia and osteoporosis [48, 49]. Although no significant improvement in BMD were seen in a 6 month vibration training [50]; muscle strength was improved [49-51].

\section{Combined hormone replacement therapy and exercise}

The addition of a brisk walking program to HRT, in this population of postmenopausal women, provided no additional changes to either bone resorption (Figures la. and $\mathrm{lb}$.) or formation indices, indicating that HRT was the primary stimulus for changes in bone turnover. Previous studies focusing on the effects combined exercise and HRT on BMD have been conflicting. Prospective studies [34] have found aerobic exercise in combination with HRT, but not exercise alone, significantly increased BMD. However, current studies have shown high intensity exercise significantly increased BMD in postmenopausal women [44, 45]. Hence, any benefit conveyed by combined treatment appeared to be attributable to HRT. In contrast, HRT and nine months of vigorous weight-bearing exercise were independently beneficial in increasing BMD, whilst combined treatment provided an additive benefit at sites of lumbar spine and Wards triangle [33]. HRT and weight lifting exercises also significantly increased BMD of the total body in women who had had a hysterectomy, but exercise was not assessed independently of HRT [52]. There are no studies that measure bone turnover markers as a result of these combined treatments.

\section{Conclusion}

The current pilot study, although in small group numbers indicated that walking alone, at the intensities and duration prescribed, was an insufficient stimulus to reduce bone turnover in early postmenopausal women, whilst HRT was an effective treatment intervention to reduce bone turnover after menopause. The combination of HRT and moderate weight bearing exercise provided no added benefit in comparison to HRT alone. A combination of resistance training and walking may be more effective in reducing bone turnover, in comparison to walking alone. Alternatively, older populations of postmenopausal women, with lower BMD values, may benefit more from walking alone.

\section{Acknowledgements}

Medroxyprogesterone acetate was kindly supplied by Pharmacia Pharmaceuticals, Rydalmere, NSW Australia. Placebo patches were kindly supplied by Novartis Pharmaceuticals, North Ryde, NSW Australia. The authors thank Dr Juliana Antonipillai for formatting and help with preparation of the manuscript.

\section{REFERENCES}

1. Delmas PD, Confavreux E, Garnero P, Fardellone P, de Vernejoul MC, Cormier C, et al. A combination of low doses of 17 beta-estradiol and norethisterone acetate prevents bone loss and normalizes bone turnover in postmenopausal women. Osteoporosis inter- 
national: a journal established as result of cooperation between the European Foundation for Osteoporosis and the National Osteoporosis Foundation of the USA. 2000; 11: 177-87.

2. Dresner-Pollak R, Parker RA, Poku M, Thompson J, Seibel MJ, Greenspan SL. Biochemical markers of bone turnover reflect femoral bone loss in elderly women. Calcified tissue international. 1996; 59: 328-33.

3. Juraschek M, Seibel MJ, Woitge HW, Krempien B, Bauss F. Association between histomorphometry and biochemical markers of bone turnover in a longitudinal rat model of parathyroid hormone-related peptide (PTHrP)-mediated tumor osteolysis. Bone. 2000; 26: 475-83.

4. Seibel MJ. Molecular markers of bone turnover: biochemical, technical and analytical aspects. Osteoporosis international: a journal established as result of cooperation between the European Foundation for Osteoporosis and the National Osteoporosis Foundation of the USA. 2000; 11 Suppl 6: S18-29.

5. Seibel MJ. Biochemical markers of bone turnover: part I: biochemistry and variability. The Clinical biochemist Reviews / Australian Association of Clinical Biochemists. 2005; 26: 97-122.

6. Seibel MJ. Biochemical markers of bone turnover part II: clinical applications in the management of osteoporosis. The Clinical biochemist Reviews / Australian Association of Clinical Biochemists. 2006; 27: 123-38.

7. Seibel MJ. Clinical application of biochemical markers of bone turnover. Arquivos brasileiros de endocrinologia e metabologia. 2006; 50: 603-20.

8. Seibel MJ, Dunstan CR, Zhou H, Allan CM, Handelsman DJ. Sex steroids, not FSH, influence bone mass. Cell. 2006; 127: 1079; author reply 80-1.

9. Woitge HW, Seibel MJ. Biochemical markers to survey bone turnover. Rheumatic diseases clinics of North America. 2001; 27: 49-80.

10, Schlemmer A, Hassager C, Delmas PD, Christiansen C. Urinary excretion of pyridinium cross-links in healthy women; the long-term effects of menopause and oestrogen/progesterone therapy. Clin Endocrinol (Oxf). 1994; 40: 777-82.

11, Rosen CJ, Chesnut CH, 3rd, Mallinak NJ. The predictive value of biochemical markers of bone turnover for bone mineral density in early postmenopausal women treated with hormone replacement or calcium supplementation. J Clin Endocrinol Metab. 1997; 82: 1904-10.

12. Garnero P, Sornay-Rendu E, Chapuy MC, Delmas PD. Increased bone turnover in late postmenopausal women is a major determinant of osteoporosis. J Bone Miner Res. 1996; 11: 337-49.

13. Guthrie JR, Ebeling PR, Hopper JL, Barrett-Connor E, Dennerstein L, Dudley EC, et al. A prospective study of bone loss in menopausal Australian-born women. Osteoporosis international: a journal established as result of cooperation between the European Foundation for Osteoporosis and the National Osteoporosis Foundation of the USA. 1998; 8: 282-90.
14. Mazzuoli G, Acca M, Pisani D, Diacinti D, Scarda A, Scarnecchia L, et al. Annual skeletal balance and metabolic bone marker changes in healthy early postmenopausal women: results of a prospective study. Bone. 2000; 26: 381-6.

15. Bischoff $H$, Stahelin HB, Vogt $P$, Friderich $P$, Vonthein R, Tyndall A, et al. Immobility as a major cause of bone remodeling in residents of a long-stay geriatric ward. Calcified tissue international. 1999; 64: 485-9.

16. Vico L, Collet P, Guignandon A, Lafage-Proust $\mathrm{MH}$, Thomas T, Rehaillia M, et al. Effects of long-term microgravity exposure on cancellous and cortical weight-bearing bones of cosmonauts. Lancet. 2000; 355: $1607-11$.

17. Macari S, Duffles LF, Queiroz-Junior CM, Madeira MF, Dias GJ, Teixeira MM, et al. Oestrogen regulates bone resorption and cytokine production in the maxillae of female mice. Archives of oral biology. 2015; 60: 333-41.

18. Westerlind KC, Wronski TJ, Ritman EL, Luo ZP, An $\mathrm{KN}$, Bell $\mathrm{NH}$, et al. Estrogen regulates the rate of bone turnover but bone balance in ovariectomized rats is modulated by prevailing mechanical strain. Proc Natl Acad Sci U S A. 1997; 94: 4199-204.

19. Prior JC, Vigna YM, Wark JD, Eyre DR, Lentle BC, Li DK, et al. Premenopausal ovariectomy-related bone loss: a randomized, double-blind, one-year trial of conjugated estrogen or medroxyprogesterone acetate. J Bone Miner Res. 1997; 12: 1851-63.

20. Jilka RL, Hangoc G, Girasole G, Passeri G, Williams DC, Abrams JS, et al. Increased osteoclast development after estrogen loss: mediation by interleukin-6. Science. 1992; 257: 88-91.

21. Kameda T, Mano H, Yuasa T, Mori Y, Miyazawa K, Shiokawa M, et al. Estrogen inhibits bone resorption by directly inducing apoptosis of the bone-r esorbing osteoclasts. The Journal of experimental medicine. 1997; 186: 489-95.

22. Horowitz MC. Cytokines and estrogen in bone: antiosteoporotic effects. Science.1993; 260: 626-7.

23. Passeri G, Girasole G, Jilka RL, Manolagas SC. Increased interleukin- 6 production by murine bone marrow and bone cells after estrogen withdrawal. Endocrinology. 1993; 133: 822-8.

24. Ralston SH, Ho LP, Helfrich MH, Grabowski PS, Johnston PW, Benjamin N. Nitric oxide: a cytokineinduced regulator of bone resorption. J Bone Miner Res. 1995; 10: 1040-9.

25. Ray A, Prefontaine KE, Ray P. Down-modulation of interleukin-6 gene expression by 17 beta-estradiol in the absence of high affinity DNA binding by the estrogen receptor. J Biol Chem. 1994; 269: 12940-6.

26. Pottratz ST, Bellido T, Mocharla H, Crabb D, Manolagas SC. 17 beta-Estradiol inhibits expression of human interleukin-6 promoter-reporter constructs by a receptor-dependent mechanism. J Clin Invest. 1994; 93: 944-50.

27. Turner CH, Takano Y, Owan I, Murrell GA. Nitric oxide inhibitor L-NAME suppresses mechanically 
induced bone formation in rats. Am J Physiol. 1996; 270: E634-9.

28. Adami S, Gatti D, Braga V, Bianchini D, Rossini M. Site-specific effects of strength training on bone structure and geometry of ultradistal radius in postmenopausal women. J Bone Miner Res. 1999; 14: 120-4.

29. Haapasalo H, Kannus P, Sievanen H, Pasanen M, Uusi-Rasi K, Heinonen A, et al. Effect of long-term unilateral activity on bone mineral density of female junior tennis players. J Bone Miner Res. 1998; 13: 310-9.

30. Huddleston AL, Rockwell D, Kulund DN, Harrison RB. Bone mass in lifetime tennis athletes. Jama. 1980; 244: 1107-9.

31. Jones HH, Priest JD, Hayes WC, Tichenor CC, Nagel DA. Humeral hypertrophy in response to exercise. J Bone Joint Surg Am. 1977; 59: 204-8.

32. Kannus P, Haapasalo H, Sievanen H, Oja P, Vuori I. The site-specific effects of long-term unilateral activity on bone mineral density and content. Bone. 1994; 15: 279-84.

33. Kohrt WM, Snead DB, Slatopolsky E, Birge SJ, Jr. Additive effects of weight-bearing exercise and estrogen on bone mineral density in older women. J Bone Miner Res. 1995; 10: 1303-11.

34. Heikkinen J, Kyllonen E, Kurttila-Matero E, WilenRosenqvist G, Lankinen KS, Rita H, et al. HRT and exercise: effects on bone density, muscle strength and lipid metabolism. A placebo controlled 2-year prospective trial on two estrogen-progestin regimens in healthy postmenopausal women. Maturitas. 1997; 26: 139-49.

35. Humphries B, Newton RU, Bronks R, Marshall S, McBride J, Triplett-McBride $T$, et al. Effect of exercise intensity on bone density, strength, and calcium turnover in older women. Med Sci Sports Exerc. 2000; 32: 1043-50.

36. Nelson ME, Fiatarone MA, Morganti CM, Trice I, Greenberg RA, Evans WJ. Effects of high-intensity strength training on multiple risk factors for osteoporotic fractures. A randomized controlled trial. Jama. 1994; 272: 1909-14.

37. Pruitt LA, Taaffe DR, Marcus R. Effects of a oneyear high-intensity versus low-intensity resistance training program on bone mineral density in older women. J Bone Miner Res. 1995; 10: 1788-95.

38. Chamay A, Tschantz P. Mechanical influences in bone remodeling. Experimental research on Wolff's law. J Biomech. 1972; 5: 173-80.

39. Ito M, Nakamura T, Ikeda S, Tahara Y, Hashmi R, Tsurusaki K, et al. Effects of lifetime volleyball exercise on bone mineral densities in lumbar spine, calcaneus and tibia for pre-, peri- and postmenopausal women. Osteoporosis international: a journal established as result of cooperation between the European Foundation for Osteoporosis and the National Osteoporosis Foundation of the USA. 2001; 12: 104-11.

40. Coupland CA, Cliffe SJ, Bassey EJ, Grainge MJ, Hosking DJ, Chilvers CE. Habitual physical activity and bone mineral density in postmenopausal women in England. Int J Epidemiol. 1999; 28: 241-6.

41. Welsh L, Rutherford OM. Hip bone mineral density is improved by high-impact aerobic exercise in postmenopausal women and men over 50 years. Eur J Appl Physiol Occup Physiol. 1996; 74: 511-7.

42. Chow R, Harrison JE, Notarius C. Effect of two randomised exercise programmes on bone mass of healthy postmenopausal women. Br Med J (Clin Res Ed). 1987; 295: 1441-4.

43. Snow CM, Shaw JM, Winters KM, Witzke KA. Long-term exercise using weighted vests prevents hip bone loss in postmenopausal women. J Gerontol A Biol Sci Med Sci. 2000; 55: M489-91.

44. Moreira LD, Fronza FC, Dos Santos RN, Zach PL, Kunii IS, Hayashi LF, et al. The benefits of a highintensity aquatic exercise program (HydrOS) for bone metabolism and bone mass of postmenopausal women. Journal of bone and mineral metabolism. 2014; 32: 411-9.

45. Moreira LD, Oliveira ML, Lirani-Galvao AP, MarinMio RV, Santos RN, Lazaretti-Castro M. Physical exercise and osteoporosis: effects of different types of exercises on bone and physical function of postmenopausal women. Arquivos brasileiros de endocrinologia e metabologia. 2014; 58: 514-22.

46. Kerr D, Ackland T, Maslen B, Morton A, Prince R. Resistance training over 2 years increases bone mass in calcium-replete postmenopausal women. J Bone Miner Res. 2001; 16: 175-81.

47. Ryan AS, Treuth MS, Hunter GR, Elahi D. Resistive training maintains bone mineraldensityin postmenopausal women. Calcified tissue international. 1998; 62: 295-9.

48. Cardinale M, Pope MH. The effects of whole body vibration on humans: dangerous or advantageous? Acta physiologica Hungarica. 2003; 90: 195-206.

49. Weber-Rajek M, Mieszkowski J, Niespodzinski B, Ciechanowska K. Whole-body vibration exercise in postmenopausal osteoporosis. Przeglad menopauzalny $=$ Menopause review. 2015; 14: 41-7.

50. Tankisheva E, Bogaerts A, Boonen S, Delecluse C, Jansen P, Verschueren SM. Effects of a Six-Month Local Vibration Training on Bone Density, Muscle Strength, Muscle Mass, and Physical Performance in Postmenopausal Women. Journal of strength and conditioning research / National Strength \& Conditioning Association. 2015; 29: 2613-22.

51. Tankisheva E, Bogaerts A, Boonen S, Feys H, Verschueren S. Effects of intensive whole-body vibration training on muscle strength and balance in adults with chronic stroke: a randomized controlled pilot study. Archives of physical medicine and rehabilitation. 2014; 95: 439-46.

52. Notelovitz M, Martin D, Tesar R, Khan FY, Probart $\mathrm{C}$, Fields $\mathrm{C}$, et al. Estrogen therapy and variableresistance weight training increase bone mineral in surgically menopausal women. J Bone Miner Res. 1991; 6: 583-90. 
Резиме

ЕФЕКТИТЕ НА ХОРМОНСКАТА

ТЕРАПИЈА И ВЕЖБАЊЕТО ВРЗ

КОСКЕНИОТ МЕТАБОЛИЗАМ

КАЈ ЖЕНИ ВО ПОСТМЕНОПАУЗА: РАНДОМИЗИРАНА, ДВОЈНО СЛЕПА ПИЛОТ-СТУДИЈА

\section{Сузи Ј Хонисет ${ }^{1}$, Кети Тангалакис ${ }^{1}$, Џон Варк ${ }^{2}$, Васо Апостолопулос', Лили Стојановска ${ }^{1}$}

${ }^{1}$ Центар за хронични болести, Школа за здравство и биомедицина, Универзитет Викторија, Викторија, Австралија

${ }^{2}$ Кралска болница во Мелбурн, Парквил, Мелбурн, Викторија, Австралија

Вовед: Хормонска заменска терапија (HRT) и пешачење беа испитувани самостојно и во комбинација за да се утврди кој третман најмногу влијаел врз коскениот метаболизам кај жени во постменопауза.

Мет̄ояи: Користејќи рандомизирана двојно слепа пилот-студија, 10 испитаници добија

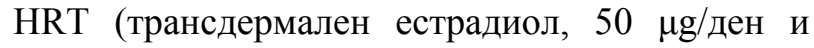
орално МРА $5 \mathrm{mg}$ /ден), а 12 примале плацебо 20 недели. По почетниот период на третманот, двете групи беа подложени на режим на пешачење, што се зголемуваше во интензитет, времетраење и параметри на зачестеност од 8 до 20 недели. Мерењата на аеробниот капацитет, женските полови хормони, маркерите за формирање на коските [остеокалцин (ОС) и коскена алкална фосфатаза (BAP)] и маркерите за коскената ресорпција [деоксипиридинолин (DPD) и пиридинолин (PYR)] беа мерени на почетокот (T1), 8. недела (Т2) и 20. недела (Т3).

Резулйайи: Возраста, времето на постменопаузата, тежината или индексот на телесна маса не беа различни помеѓу секоја од групите. Групата на HRT имаше значително повисоки нивоа на естрадиол во споредба со плацебо групата во T2 и T3. Нивоата на FSH и LH беа значително намалени по HRT. DPD и PYR беа значително намалени од почетните нивоа на T2 и T3 со HRT. Немаше значајни промени кај нивоата на ОС или ВАР, со HRT или пешачење. Пешачењето не ги промени маркерите на коскениот метаболизам кај HRT или плацебо групата.

Заклучок: HRT jа намалува коскената ресорпција, сепак, само пешачењето според пропишаниот интензитет и времетраењето, или комбинацијата на HRT и пешачење, не дадоа дополнителна корист по менопаузата. Затоа, HRT, но не и пешачењето, е ефективен третман за намалување на коскениот метаболизам кај жени во постменопауза.

Клучни зборови: вежба, хормонска заменска терапија, HRT, коскен метаболизам, менопауза, естроген 